\title{
MAGYARORSZÁG TÉRINFORMATIKAI ALAPÚ GYORSFORGALMI ÁTJÁRHATÓSÁGI VIZSGÁLATA AZ ELEKTROMOBILITÁS SZEMPONTJÁBÓL - HELYZETKÉP ÉS FEJLESZTÉSI LEHETŐSÉGEK
}

\author{
SOHA TAMÁS - NÉMETH IZABELLA - MUNKÁCSY BÉLA \\ GIS-BASED CONNECTIVITY ANALYSIS FROM THE PERSPECTIVE OF E-MOBILITY \\ ON HUNGARIAN MOTORWAYS \\ - CURRENT STATUS AND POSSIBLE DEVELOPEMENTS
}

\begin{abstract}
In the context of this research, two aspects, namely coverage and linear availability, have been examined for the possibility of quick charging of battery-powered electric vehicles in Hungary, focusing on national connectivity. It has been shown that the density of quick chargers is uneven; that is, they are present in the inner cities at a higher rate than along motorways for long-distance transport. The study carried out comparative analyses based on two previously published concepts (E.ON-MOL and BME KKT) and a dedicated methodology (ELTE KTF) using the potential charging sites outlined therein. Modelling has shown that the electric car charging possibilities available along the highways are limited. The investigation suggests that the strategic objective should not be to establish a charging network for national connectivity, since only $5 \%$ of the charging stations are currently located in the immediate vicinity of motorways and only half of which are quick chargers.
\end{abstract}

Keywords: battery-powered electric vehicles; quick charging; spatial optimisation; connectivity; Hungary

\section{Bevezetés}

Az energiarendszer ma megmaradt természeti eróforrások egyik legnagyobb fogyasztója, illetve lokális és globális környezetünk legjelentősebb szennyezője. Napjainkban a szektor gyökeres átalakulása folyik, ennek számos lényegi eleme közül kiemelkedik a terhelés csökkentésének szándéka. Erre kézenfekvő megoldás a tisztábban felhasználható megújuló energiaforrásokra való átállás és a villamos energia egyre általánosabbá válása az energiaszolgáltatások minden területén, így a hő- és a közlekedési energetika vonatkozásában is. Éppen tíz esztendeje, 2010-ben indult meg az első, nagy szériában értékesített elektromos autómodell, a Nissan Leaf gyártása. Ez azt is jelenti, hogy tíz éve lényegében még nem létezett töltési infrastruktúra sem. Hazánkban például ugyancsak 2010-ben telepítették az első ilyen állomást.

Napjainkra a töltôhálózat váza kialakult, és az elektromos autók, illetve az ezekkel párhuzamosan fejlődő, lényegesen alacsonyabb környezetterhelésű villamosáram-termelő technológiák (főként szélerőmúvek és napelemek) révén radikális javulást érhetünk el az erőforrás-felhasználás hatékonyságában és a kibocsátás-csökkentésben egyaránt. Különösen jelentős javulás várható a nagy forgalmú, erősen szennyezett levegőjú városi terekben, ahol ráadásul számos más lehetőség is van a környezetterhelés csökkentésére (pl. a munkaszervezés optimalizálása, kerékpáros-központú településfejlesztés, a közösségi közlekedés minőségének javítása). Bár a városi terekben történő, jellemzően rövid távú utazások a megfelelő töltési infrastruktúra révén nem ütköznek akadályba, a nagyobb távolságok megtételérôl ugyanez már nem mondható el. Az elektromos személyautók hosszabb uta- 
zásokra való alkalmazása fóként akkumulátoraik kapacitásától, az üzemi körülményektől, illetve a töltési lehetóségektól függ. Az egyre nagyobb és hatékonyabb akkumulátorok egyértelmúen hosszabb utazásokat tesznek lehetővé, azonban a megfelelő töltési infrastruktúra ugyanilyen súllyal kell, hogy szerepeljen az elektromobilitás (e-mobilitás) fejlesztése során. Amíg a múszaki fejlesztés elsősorban a személyautókat gyártó vállalatok mérnökeinek feladata, addig az infrastruktúra-fejlesztés az adott földrajzi terület döntéshozóira és az őket támogató területfejlesztési szakemberekre hárul. Ez utóbbi kapcsán törekedni kell arra, hogy megfelelő töltőhálózat jöjjön létre, amely a szakirodalomban „hatótáv-aggodalom”-nak (range anxiety) nevezett jelenséget háttérbe szorítva megteremti az ország átjárhatóságának múszaki feltételeit (PEVEC, D. et al. 2020). Ennek kulcsfontosságú eleme a gyorsforgalmi utak mentén kiépülő, nagyobb távolságok biztonságos megtételét lehetővé tevő, gyors, és minden felhasználó számára garantált hozzáférést biztosító, megfizethető szolgáltatást kínáló töltési infrastruktúra.

A kulcskérdés az, hogy milyen döntéshozói szinteken, mikor ismerik fel, hogy az „,energiaforradalom" megvalósítása, és ezen belül (többek között) a közlekedési szektor fenntarthatóvá tétele elkerülhetetlen. A 2019 decemberében útjára indított „European Green Deal” arra utal, hogy az Európai Unió vezetői részéről ez a felismerés már megtörtént. Ambiciózus célként az „első klímasemleges kontinens” létrehozását tűzték ki 30 éves időtávlatban, amelyben a fenntartható mobilitás is lényeges szerepet kap (Európa Tanács 2019). Dánia felelős kormánya - magyar szemmel - egészen elképesztő terveket fogalmazott meg nemzeti energia- és klímatervében, hiszen már 2030-ra 109\%-os megújulóenergia-részarányt tervezett a villamosenergia-termelésben. Ugyanezzel a céldátummal szerepel a tervben a belsóégésú motorral szerelt gépjármúvek dániai forgalmazásának megszüntetése (DMCEU 2019), ami pedig azt is feltételezi, hogy sok tekintetben még korlátozott használhatóságukat sikerül jelentôsen javítani.

Jelen kutatás célja, hogy elérhetőségi vizsgálatokon keresztül feltárja, milyen módon befolyásolja hazánkban az elektromos autózás elterjedését a jelenlegi töltési infrastruktúra, különös tekintettel a leggyorsabb töltési lehetőséget kínáló villámtöltésre, illetve összehasonlítja a töltőpontok elhelyezését célzó fejlesztési javaslatok hatékonyságát.

\section{Az elektromosautó-töltóállomások telepítését vizsgáló kutatások áttekintése}

A témával foglalkozó nemzetközi szakirodalom már a technológia megjelenésétôl kezdve, többféle szempontból vizsgálja az e-mobilitást kiszolgáló infrastruktúrához kapcsolódó problémakört. HodGson, M. J. (1990) FCLM- (Flow Capturing Facility Location Models) modellje számos tanulmány alapját képezte. A szerző a vonal menti igényt kiszolgáló létesítmények elhelyezésének lehetőségeit modellezte, megalapozta a szakaszorientált telepítési koncepciót, ezáltal módszertana a potenciális töltőállomások telepítésének optimalizálásában alapvetô kiindulóponttá vált. KUBY, M.-LiM, S. (2004) is a FCLM-modellt egészítette ki az elektromos autók számára szükséges töltőállomásokkal. Elemzésükben az optimális helyszínek a járművek hatótávjától, az utazás hosszától és az úthálózat sűrűségétől függenek.

AlEGRE, S. et al. (2017) tanulmánya már új megközelítést kínál a töltőállomások tervezésére szolgáló szoftverek fejlesztésében. A korábbi vizsgálatoktól eltéróen az elektromos jármúveket is indikátornak tekintették és a Matlab/Simulink segítségével modellezték is teljesítményüket. A GIS-alapú szimuláció során figyelembe vették az autó aerodinamikáját, tömegét, az akkumulátor kapacitását, a vezetési módot, az időjárás lehetséges változásait, az út típusát, valamint a töltők közötti távot - és ezek alapján tettek javaslatokat a töltő́llomások telepítésére. 
A létesítmények térbeli elhelyezésének optimalizációjára számos kutatás alkalmaz térinformatikai eljárásokat, mind a területi lefedettség maximalizálása (FRADE, I. et al. 2011; CAPAR, I.-Kuby, M. 2012; Chung, S. H.-Kwon, C. 2015), mind pedig a közúthálózaton való elérhetőség és a töltőpontok számának minimalizálása szempontjából (SHAHRAKI, N. et al. 2015; HanabusA, H.-Horiguchi, R. 2011). LiU, J. (2012) Peking és fokozottan urbanizált környezete példáján tárta fel a városi környezetben leginkább megfelelő töltési helyszíneket, rövidebb utazásokat feltételezve, valamint felhívta a figyelmet a 24 milliós lakosú város nagyléptékú elektromosautó-használatának a villamosenergia-rendszerre gyakorolt lehetséges hatásaira. Ezzel szemben He, Y. et al. (2019) kifejezetten a hosszú távú utazásokra és az ezekkel összefüggésben levő villámtöltési lehetőségekre fókuszált a töltôpontok helyszín-optimalizációja során. DoNG, G. et al. (2019) tanulmányában hangsúlyosan jelennek meg a vizsgált terület népsúrúségi adatai és közúti forgalmi jellemzők.

Az ilyen jellegú hazai kutatások száma igazán szerény. GERSE J. (2020) statisztikai, illetve részben ezek hiányában nem hivatalos adatbázisokat használva mutatta be az elmúlt évek elektromobilitási fejlődését. Tanulmányában térképes megjelenítés segítségével mutatja be a nyilvános töltőpontok területi eloszlását és ezen infrastruktúra elérhetőségének nehézségeit. CsiszÁR Cs. és szerzőtársai (2018) országos léptékben, ugyancsak térinformatikai támogatással állapították meg a potenciális töltőállomás-helyszíneket. Fő céljukként nevezték meg, hogy olyan töltôhálózatra tegyenek javaslatot, amely biztosítja az ország átjárhatóságát - bár módszertanukat inkább országos lefedettségi vizsgálatként értelmezhetjük. Első lépésben megállapították a stratégiai helyszíneket, majd szúkítették a lehetőségeket a potenciális töltőállomásokra. Ezek kijelölése után kiszámolták a lefedettséget, végül meghatározták a szükséges töltőpontok számát az egyes töltőállomásokon. Azonban a potenciális töltőpontok köré vont egység sugarú körök mint ellátási területek kevésbé realisztikusak, mert az általuk ellátott területek úthálózatát gyakorlatilag utakkal homogén módon átszőtt síkbeli szövetnek tekinti. A tanulmány konklúziója, hogy töltőállomás-helyszíneket a jelentősebb forgalmú utak mellé szükséges telepíteni.

A témát érintő szakirodalom által bemutatott eredmények alapján konszenzus van abban, hogy a fớtvonalak mentén számos tényező befolyásolja a töltési igényt, ám ezek közül a forgalom nagysága és az elektromos autók hatótávolsága a legmeghatározóbb. Sok esetben a tanulmányok nem foglalkoznak a töltési idővel, pedig ez a tényező a hosszú távú utak megtétele szempontjából döntő fontosságú.

\section{Módszertan}

A felhasználói tapasztalatok alapján hazánkban a gyorsforgalmi utak mentén a hosszabb távú utak megtételéhez szükséges töltési lehetôségek hiányosan vannak jelen. A tanulmányozott szakirodalom alapján számos indikátort használhatunk fel ahhoz, hogy a lehető legpontosabban lehessen ábrázolni az aktuális helyzetet, azonban a töltési idő (gyorsés villámtöltő) és a térbeliség a legtöbb kutatástól eltérően kulcsfontosságú szempontként jelenik meg munkánk során. Fontos szempontként érvényesítettük, hogy a hosszú távolságokat minél gyorsabban és zökkenőmentesen lehessen megtenni, ezért csak az általánosan használható CHAdeMO (japán) és CCS (európai) szabvány szerint múködő villámtöltőkre (40 kW-nál nagyobb töltési teljesítmény) összpontosítottunk a modellezés során - ezek a nemzetközi szakirodalomban , quick charger”-ként jelennek meg, szemben az alacsonyabb teljesítményű „fast charger”-rel. A Tesla Supercharger és Ionity töltóállomásokat a vizsgálat során nem vettük figyelembe, mert ezek nem minden felhasználó számára elérhetők. 


\section{A jelenlegi EV átjárhatóság modellezése}

Egységes, állami kezelésú adatbázis hiányában a Mobiliti mobiltelefonos applikációja alapján készítettük el azt az adatbázist, amely tartalmazza a 2019. szeptember 12-ig telepített, összes nyilvános töltőállomás jellemzőit és pontos földrajzi pozícióját, tekintet nélkül a telepítést és üzemeltetést végző piaci szereplőkre. A létrehozott adatbázis nem tartalmazza azonban a Budapest területén levő töltőket, hiszen országos viszonylatban kiemelkedő sűrûségük és lokális szolgáltatásuk miatt a kutatás szempontjából nem relevánsak. A vizsgálatok elvégzéséhez felhasználtuk továbbá az Open Street Map (OSM) Magyarországra vonatkozó közúthálózatának téradatait. Az egyes útszakaszok forgalmát a keresztmetszeti mértékadó óraforgalommal (MOF) definiáltuk (MK Nonprofit Zrt. 2018). A térinformatikai modellezés az ArcMap 10.2-es munkakörnyezetében történt, amelyhez a Network Analyst eszközcsomag Service Area opcióját alkalmaztuk az areális lefedettségi és lineáris elérhetôségi vizsgálatokhoz.

\section{Villámtöltési lehetôségek areális lefedettség-vizsgálata}

Az egyes villámtöltő állomások országos areális lefedettség-vizsgálatához a töltőállomásoktól távolodva 20 km-es, közúton értelmezett zónákat hoztunk létre. Mivel jelenleg a piacon lévő elektromos autók közül a hazánkban egyik leggyakoribb, átlagosnak tekinthető, második generációs, nettó 36 kWh-s akkumulátorral szerelt Nissan Leaf kedvező üzemi körülmények között elérhető hatótávolsága 260 km, ezt tekintettük az elemzés során „maximális távolságnak”. Valós körülmények között ez a modell egy töltéssel 200-210 km megtételére alkalmas autópályán.

Ellentétben a pufferzónás ellátásiterület-kijelölés egységsugarú kör alapú zónáival, a Service Area eszköz pontosabb eredményt rajzol ki. A szoftver nemcsak közúton ábrázolja a határokat, hanem feltételezi, hogy a hálózatban felhasznált útszakaszok közötti üres térben szintén lehetnek alacsonyabb rendű, a vizsgálatban részt nem vevő utak. Így az egyes távolsági kategóriák a vizsgálatban résztvevő közúttal való metszéspontjai alapján végez térbeli interpolációt két szomszédos, egymáshoz közeli útszakasz közötti térrész kitöltésére. Az egyes villámtöltők körül kijelölhető, azonos távolsági értékű szomszédos zónákat összevontuk a realisztikusabb és egységes megjelenítés érdekében.

\section{A villámtöltési lehetőségek lineáris elérhetöségi vizsgálata}

A lineáris elérhetőségi vizsgálat esetében kifejezetten a gyorsforgalmi utakat és az azok mentén elérhető villámtöltőket vettük figyelembe, hogy a modellezés során az ország átjárhatósága kerüljön a vizsgálat középpontjába. A számításokhoz, illetve az eredmények ábrázolásához - az areális lefedettség vizsgálatával ellentétben - nem poligont, hanem vonalas megjelenítést alkalmaztunk, és szintén 20 km-es osztályközöket használva, a villámtöltési lehetőségektől való 260 km-es elméleti maximális eljutási távolságot vettünk figyelembe.

A modell a kijelölt kiindulóponttól távolodva (figyelembe véve a menetirány szerinti két oldalt, vagyis az egyes útpályák egyirányúságát) a hálózat alapját képző autópályákra vetítve jelöli ki az elérhetô útszakaszt, egészen a meghatározott maximális távolságig. Amennyiben a hálózaton még a maximális távolság elérése előtt újabb töltőpontba ütközik, a kiindulási pontra vonatkozó szolgáltatási terület véget ér, és új útszakasz kijelölésébe kezd az új töltőpontot kezdőpontként felhasználva. Ha a modellezett személyautó indulási helyétôl 260 km-en belül új töltőállomással találkozik, feltételezzük, hogy ott minden esetben él a töltési lehetőséggel annak érdekében, hogy az elméleti maximális hatótávolságát kihasználhassa. Ha a következő töltőpont 260 km-nél távolabb helyezkedik el, a szol- 
gáltatási terület véget ér, ami az akkumulátor lemerülésének felel meg. Fontos azonban megjegyezni, hogy a valóságban egy elektromos személyautó hatótávolságát több tényező befolyásolja, sưrún telepített töltőállomások esetén pedig valószínútlen, hogy a jármú vezetôje minden alkalommal megáll az elérhető maximális akkumulátor-töltöttség fenntartása érdekében.

A lineáris vizsgálat során első körben kétféle modellezés készült, amelyek a teljesség igénye nélkül mutatják be a hosszú távú utazásokat lehetővé tevő hazai töltőtelepítési koncepciót, illetve - sokkal inkább - annak hiányosságait. Az egyik esetben elektromos személyautók Budapestről való indulását feltételeztük, az autópályákon a fővárostól minden esetben távolodva. Ennek alapján csak az útpályák kivezető oldalait, illetve a közvetlenül ezek pihenőiben üzemelő villámtöltők elhelyezkedését vettük figyelembe. A modellezés helyes múködése érdekében a meglévőkkel azonos tulajdonságúnak tekintett fiktív töltőpontokat jelöltünk ki az autópályák budapesti kezdőpontjain, feltételezve, hogy az elektromos autók teljes feltöltöttséggel indulnak útnak. Ebben az esetben azonban felmerül a kapcsolódó gyorsforgalmi utak szolgáltatási területeinek átfedési problémája. Ez leginkább az M0-s körgyúrú környezetében léphet fel, ahol a szomszédos autópályák le- és felhajtási lehetőségei miatt a szoftver által generált egyes „szolgáltatási területek” átfedésben lehetnek, ezért felülírhatják egymást, hibás értékeket eredményezve. A probléma feloldása érdekében a hálózat módosítására, vagyis bizonyos fel- és lehajtók csatlakozási lehetőségeinek megszüntetésére volt szükség.

Egy másik lineáris elérhetóségi vizsgálat során a modellezés rugalmasabb feltételekkel készült. Ebben az esetben a gyorsforgalmi utak $5 \mathrm{~km}$-es sugarán belüli területeken elhelyezkedő, meglévő villámtöltő́k mindegyike részt vett a vizsgálatban, tekintet nélkül a kiindulási helyzetre és a menetirány szerinti oldalakra. A modell futtatása során nemcsak az autópályákról való letérés lehetősége volt adott, de még az azokat keresztező és csatlakozással rendelkező felüljárókon keresztül való visszafordulás is. Az így létrejövő, számtalan töltőállomás-elérési útvonalból fakadó ellátási területek átfedései miatt nem végeztük el a probléma kiküszöbölését célzó hálózatmódosítást. Mivel a releváns villámtöltők elemszáma az előző lineáris modellezéshez képest magasabb, az autópályák Budapestről induló kezdőpontjain nem alkalmaztunk fiktív töltőpontokat. Ehelyett az autópályáknak az országba belépó pontjaira, illetve az M3-as autópálya vásárosnaményi, jelenleg töltőhiányos elvégződéséhez helyeztünk fiktív villámtöltési pontokat. Az eljárás az areális lefedettségi vizsgálathoz hasonlítható, az eredmények pedig a gyorsforgalmi úthálózat egy véletlenszerúen választott pontja és a legközelebbi villámtöltési lehetőség közötti, közúton értelmezett távolságot adják meg.

\section{Hálózatbővítés esetén létrejövó átjárhatóság modellezése}

A jelenlegi gyorsforgalmi átjárhatóság vizsgálatán túl, potenciális, különböző szempontok szerint megvalósítható, a villámtöltő-infrastruktúrát érintő lehetséges fejlesztések modellezését is elvégeztük. Három olyan lehetőséget vizsgáltunk meg, amelyek más-más megközelítésből tesznek javaslatot a jövőben telepítendő villámtöltők helyszíni kijelölésére. Ezek között szerepel $a$ ) egy profitorientált versenypiaci szereplő (E.ON-MOL) koncepciója; $b$ ) egy tudományos megközelítésú, racionális tervezésen alapuló (CsISZÁR Cs. et al. 2018) koncepció, amelyre a továbbiakban BME KKT (Budapesti Múszaki és Gazdaságtudományi Egyetem, Közlekedésüzemi és Közlekedésgazdasági Tanszék) megnevezéssel hivatkozunk; valamint $c$ ) a két koncepció előnyeit ötvöző helyszínkijelölési eljárás, a továbbiakban ELTE KTF (Eötvös Loránd Tudományegyetem, Környezet- és Tájföldrajzi Tanszék), amelyet az előző kettő eredményeinek tanulságai alapján hoztunk létre. 


\section{Az E.ON-MOL bóvítési terveinek vizsgálata}

Az E.ON Hungária Zrt., a MOL Nyrt. és a Nissan magyarországi leányvállalatának kooperációja keretében egy hozzávetőleg 150 km-es sûrúséggel telepített, univerzális villámtöltő-hálózatot építenének ki a jövőben az európai tranzitútvonalak mentén, közvetlenül a MOL-csoporthoz tartozó töltőállomás-gerinchálózaton. Feltételeztük, hogy a vállalat minden meglévő üzemanyagtöltő-állomásán villámtöltőket telepítenek, majd ezt a halmazt kiegészítettük az autópályákon már jelenleg is elérhető elektromos töltőállomásokkal. Ebben az esetben is alkalmaztunk fiktív töltôpontokat az autópályák kiindulópontjainál, azonban a vizsgálatot egy időben mind a két menetirányban elvégeztük. Ennek oka, hogy a legtöbb esetben (az Annahegyi és az Arrabonai pihenőhely kivételével) a MOL-csoporthoz tartozó benzinkutak párosan helyezkednek el az autópályák mentén.

\section{A BME KKT eredményeinek vizsgálata}

Tudomásunk szerint jelenleg csupán egyetlen ilyen jellegú tudományos publikáció született (Csiszár Cs. et al. 2018). E kutatás célja egy országos lefedettséget biztosító töltôhálózatra való javaslattétel, éppen emiatt nem a gyorsforgalmi utakon való hosszú távú közlekedés lehetôvé tétele volt a fó szempont. Ennek ellenére az eredmények vizsgálata az autópályákon nagy számban kijelölt töltőhelyszínek miatt indokolt. A kutatásban javasolt lehetséges töltőhelyszíneket az adatbázisba integráltuk, ezek közül az autópályákra javasolt 70-et vizsgáltuk meg az gyorsforgalmi úthálózat átjárhatóságának szempontjából. Az E.ON-MOL javaslatainak vizsgálatához hasonlóan fiktív töltőpontokat és a már meglévő töltőállomásokat is figyelembe vettük a modellezés során.

\section{Az ELTE KTF kutatási módszertan bemutatása}

A módszertan kidolgozása során az volt a célunk, hogy a fent bemutatott két villámtöltő-telepítési szemlélet metszeteként, komplex megközelítést alkalmazva hasznosítsuk azok kedvező tulajdonságait. Ezek alapján az alábbi három fő szempont alkalmazásával dolgoztuk ki a módszertant:

1. Az E.ON-MOL-koncepció a meglévő töltőállomás-infrastruktúrára - mint szolgáltatásokkal (étkezési lehetőség, mosdó stb.) rendelkező helyszínekre - alapoz. Ez a megközelítés (érthető üzletstratégiai okokból) csak a saját üzemanyagtöltőállomás-hálózat elemeit veszi figyelembe, illetve negligálja az adott útszakaszra jellemző közúti forgalom szerepét. Ezzel szemben a saját módszertanban az autópályák mentén elérhető, más szolgáltatók benzinkútjait is figyelembe vettük potenciális helyszínekként.

2. A BME KKT-kutatás már figyelembe veszi a várható gépjármúforgalmat, de azt az egyes települések lakosságszámából származtatja, és nem a gyorsforgalmi utak gépjármúforgalmi adatait használja kiindulásként. Ennek ellenére telepítési szempontként jelenik meg az egyes helyszínek szolgáltatási szintje is, ami valóban befolyásolhatja a várható kihasználtságot.

3. A két helyszínkijelölés közül azonban egyik sem veszi figyelembe a javasolt töltópontok között fennmaradó (az elektromos autók kisebb hatótávolsága miatt jelentkező), az elektromos töltóállomások szempontjából hiányos útszakaszokat.

A gyorsforgalmi utak mentén telepíthető töltőállomások optimális helyszíneinek meghatározásához kétkörös eljárást alkalmaztunk. Az első körben minden pihenőhely esetében meghatároztuk az autópálya adott oldalára vonatkozó MOF-értékeket (MK Nonprofit Zrt. 2018). A 707-től (Kántorjánosi pihenő, M3) 11073-ig (Csepel, M0) terjedő tartományt természetes törések alapján három csoportra osztottuk. Az alacsonyabb forgalmú szakaszok két csoportjában (MOF $\leq 5183)$ kijelöltük az benzinkúttal rendelkező összes pihenőt, illetve azokon kívül minden nagyobb forgalmú (MOF $\geq 5184)$ szakasz mentén lévő pihenőhelyet, 
még abban az esetben is, ha benzinkút vagy más szolgáltatás nem vehetô igénybe az adott helyszínen. Az így kiválasztott 99 helyszín kibővült a már jelenleg is meglévő (bár néhány esetben átfedésben levő) villámtöltők helyszíneivel, illetve az autópályák végére elhelyezett, ebben az esetben is alkalmazott fiktív töltőpontokkal. További 84 olyan helyszín van, amely az említett kritériumok egyikének sem felel meg, tehát az első körben nem került kiválasztásra. Az első körös kijelölés a fentebb ismertetett 1. és 2. szempontot ötvözi. Az elérhetőségi vizsgálat elvégzése után kirajzolódtak azok az útszakaszok, amelyek valamely kijelölt ponttól 50 km-nél nagyobb távolságra helyezkednek el.

E problémás szakaszok kiküszöbölését célozta meg a második körös helyszínkijelölés, amiben a 3. fó szempont jelenik meg. Az ilyen, első körből származó villámtöltővel le nem fedett útszakaszokat megelőző közúton értelmezett legközelebbi pihenőhelyeket vettük számításba (7), tekintet nélkül az ott elérhető szolgáltatás minôségére. Ezeket az első körben kijelölt pihenőkkel összevonva, újból elvégeztük az elérhetőségi vizsgálatot az elektromos autóval nehezen elérhető, töltőhiányos útszakaszok hosszának csökkentése érdekében.

\section{Eredmények}

\section{Az elektromos töltőállomások infrastruktúrájának helyzete Magyarországon}

Az elhelyezkedés szempontjából jelentős területi egyenlőtlenségek figyelhetôk meg: Nyugat-Magyarországon súrúbben vannak töltőállomások, a kelet-magyarországi térségben szerényebb az ellátottság. A megyeszékhelyeket tekintve viszonylag egyenlő az eloszlás, míg a városokban és a nagyobb településeken elszórtan állnak rendelkezésre töltőpontok. Két sűrúbb a hálózatú, kiemelt terület van az országban: Budapest és környéke (kifejezetten az M0-s autóút környezetében) és a Balaton térsége.

A töltők típusát tekintve, az országban döntően gyorstöltők állnak rendelkezésre, ami összhangban van az európai trendekkel. A vizsgálatban összesen 475 Budapesten kívüli, az elterjed csatlakozó-típusokkal használható nyilvános töltőpont szerepelt, ebből 369 gyors és 96 villámtöltó. A villámtöltők közül 52 található a gyorsforgalmi utak $5 \mathrm{~km}$-es körzetében, a közvetlenül az autópályák pihenőiben elhelyezett berendezések száma pedig nem több, mint 10.

Az elektromos autók száma 2020 májusára éppen meghaladta a 9 ezret. Érdekes adalék, hogy a PWC Magyarország (2013) elemzésének „realista” forgatókönyve 2020-ra hazánkban 25650 nyilvános töltőponttal és 45 ezer elektromos autóval számol (a „,peszszimista" forgatókönyv pedig 15675 töltővel és 27500 e-autóval). Ezek az előrejelzések jóval felülmúlják a tárgyévben rendelkezésre álló töltők számát még annak tudatában is, hogy az egyes töltőállomásokon rendszerint több töltőpont vagy csatlakozási lehetőség is rendelkezésre áll.

\section{Areális elérhetôség: villámtöltők országos lefedettsége}

A jelenlegi országos lefedettséget tekintve megfigyelhető, hogy a villámtöltők az autópályák és a főutak közelében nagyobb számban, sok esetben belterületen találhatók, ugyanakkor számos, még akár városi ranggal is rendelkező településen hiányoznak (1. ábra). A villámtöltők helyétôl számított $20 \mathrm{~km}$-en belülre eső területek az ország 28,2\%-át, míg a 20 és $40 \mathrm{~km}$ között fekvő területek a 45\%-át fedik le. A 40 és $80 \mathrm{~km}$-es távolságból elérhető területek összesen 26,15\%-ot foglalnak el, és a 80 km-nél távolabbi területek már csak 
kevesebb, mint 1\%-ban vannak jelen. A villámtöltőktől 100 km-nél nagyobb távolságban lévő területek az északkeleti határ mentén vannak elenyésző mértékben.

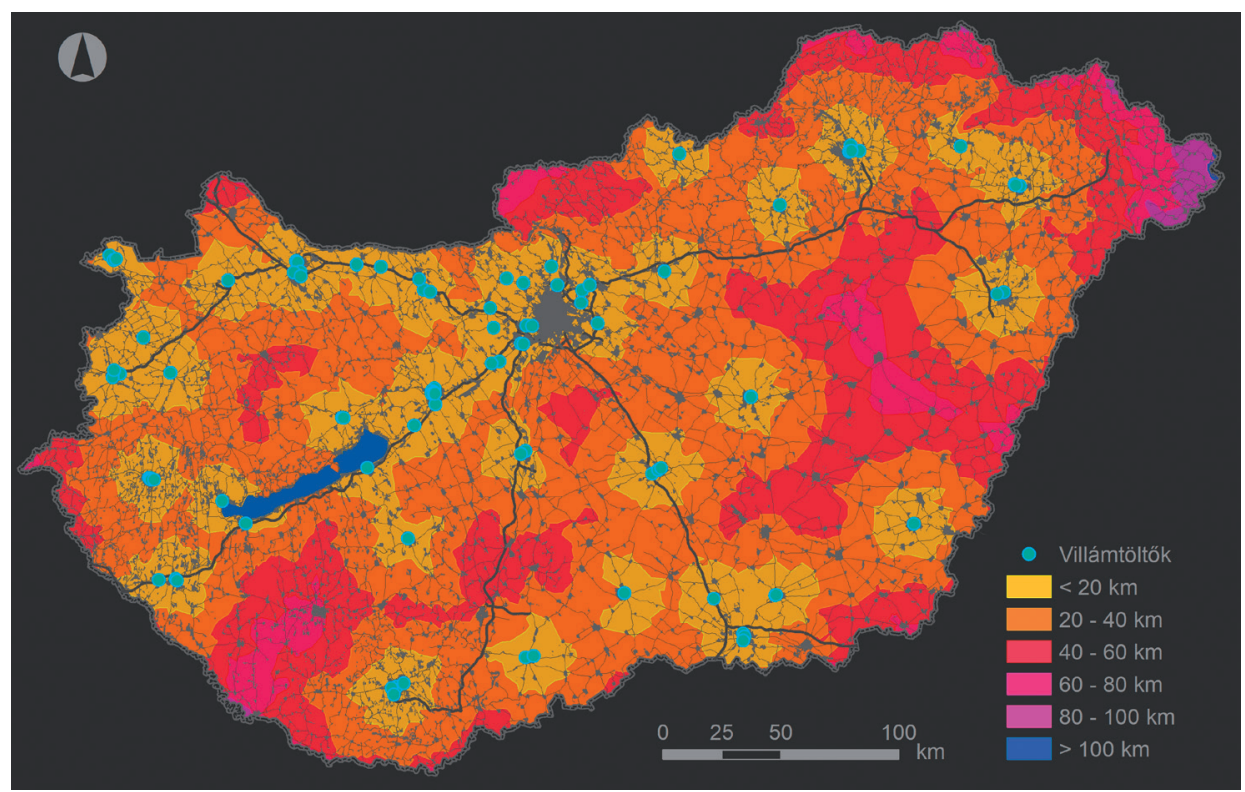

1. ábra Villámtöltők országos elérhetősége az areális lefedettség-vizsgálat alapján Figure 1 National connectivity of quick chargers according to the areal coverage analysis

\section{Lineáris elérhetöség: autópályákon közvetlenül elérhető töltóállomások}

\section{Elérhetöség Budapestról indulva és távolodva}

Budapestről történő indulás esetén is modelleztük az elérhetôséget, azokat a töltőállomásokat figyelembe véve, amelyek a fővárosból kivezető sávban találhatók - ez jelenleg mindössze 3 villámtöltőt jelent (Gödöllőn, Kajászón és Mocsán). Az autópályák budapesti kiindulópontjaira elhelyezett fiktív töltőpontoktól számított $60 \mathrm{~km}$-en belüli útszakaszok 42\%-át, a 60 és 120 km közöttiek 23\% -át, míg a 120 km-tôl 180 km-ig tartó szakaszok $21 \%$-át adják a teljes úthossznak (2. ábra). Az ennél távolabbra eső útszakaszok (180-260km) már kevésbé tekinthetők biztonságosan elérhetőnek.

Az eredmények alapján kijelenthető, hogy egy tisztán elektromos meghajtású, középkategóriás személyautó az országon belül nagyobb távolságok megtételére jelen feltételek mellett nem alkalmas, mert ezt az infrastruktúra nem teszi lehetővé.

\section{Autópályák közelében elérhető töltóállomások}

A pihenőkben elhelyezett töltőállomások hiányából származó elérhetôségi problémák nagymértékben csökkenhetnek, ha az autópályákhoz közeli töltőállomásokhoz való lehajtás, vagy a visszafordulás lehetőségét is figyelembe vesszük. Ez utóbbi miatt nem volt szükség az útirány meghatározására vagy bármely egyéb útvonal-választási megkötésre. A vizsgálatban 52 villámtöltő szerepelt, bár közülük mindössze 10 fekszik az autópályák mentén. Az esetek 40\%-ában a töltôhelyszínek az autópályák közelében fekvő, nagyobb városainkban találhatók, ezáltal több lehetóség áll rendelkezésre egy elektromos autó feltöltésére (3. ábra). 


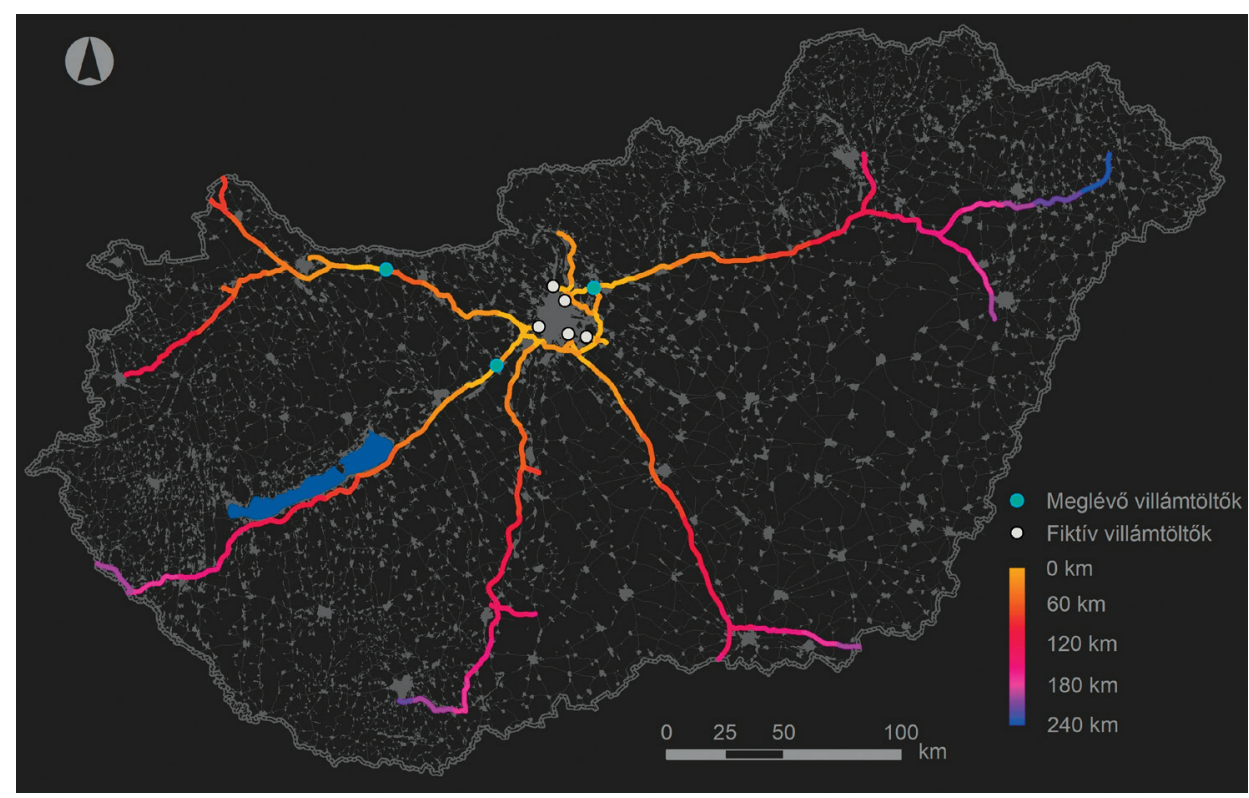

2. ábra Autópályák elérhetősége Budapestről indulva Figure 2 Highway accessibility from Budapest

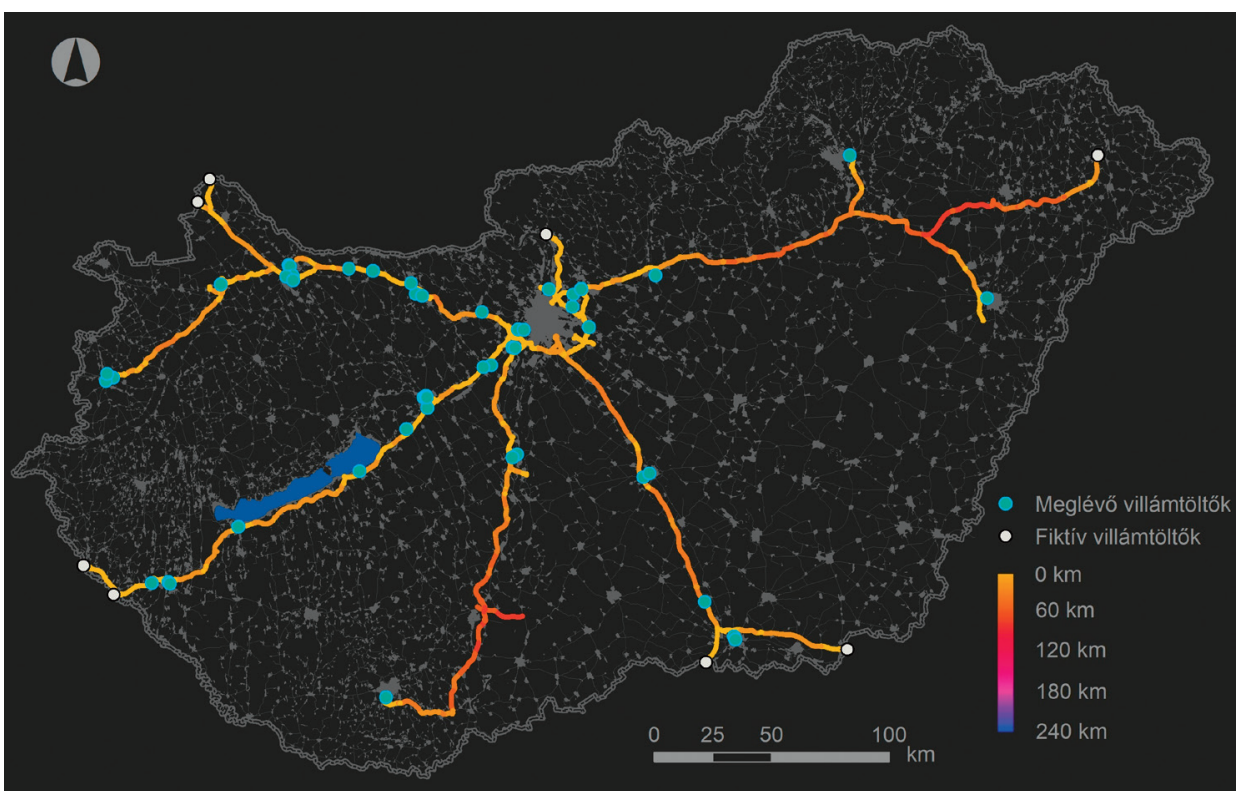

3. ábra Elérhetőség az autópályák 5 km-es körzetén belül levő villámtöltők használata esetén Figure 3 Quick charger accessibility in a $5 \mathrm{~km}$ area of highways

Az elemzés szerint az autópályák összes úthosszának 49\%-a az elektromos töltőállomásoktól számított 20 km-en, míg 29\%-a 20-40 km-en belül található, azonban ebbe 
beleértendők a távolabbi töltőponthoz való eljutáshoz szükséges rövidebb, összekötő útszakaszok. Ez alapján a modellezéshez felhasznált töltők elhelyezkedése már elegendő lenne az országos átjárhatóság szempontjából, bár ebben az esetben figyelembe kell venni, hogy az autópályáról való lehajtás többletidóbe és -energiába kerül, ami a hosszú távú közlekedés ellen hat.

\section{Hálózatbővités esetén létrejövő átjárhatóság}

\section{Az E.ON-MOL bövítési tervek vizsgálatának eredménye}

Az autópályák mentén üzemelő 34 MOL-töltőállomáson telepítendő, a már jelenleg is elérhetô villámtöltők, illetve az ezen utak kezdőpontjaira helyezett fiktív töltôpontokkal együtt 53 helyszín vett részt a modellezésben, aminek eredményeit a 4. ábra szemlélteti. A gyorsforgalmi utak vizsgálatban szereplő teljes hosszához képest $(2825 \mathrm{~km})$ a töltőpontoktól számított 20 km-es távolságon belülre eső szakaszok 38\%-ot tesznek ki, míg a 20 és 40 km közöttiek 28,6\%-ban, a 40 és 60 km közötti szakaszok 18,6\%-ban részesednek a teljes úthosszból. Ez a három távolság-kategória $(0-20 ; 20-40 ; 40-60 \mathrm{~km})$ magába foglalja az autópályák teljes hosszának 85\%-át. Ennek értelmében az E.ON-MOL célkitűzésében szereplő potenciális töltőállomások megfelelő számban vannak jelen ahhoz, hogy az együttmúködésben megfogalmazott, kelet-közép-európai régió átjárhatóságának biztosítása legalább Magyarország esetében kivitelezhető legyen.

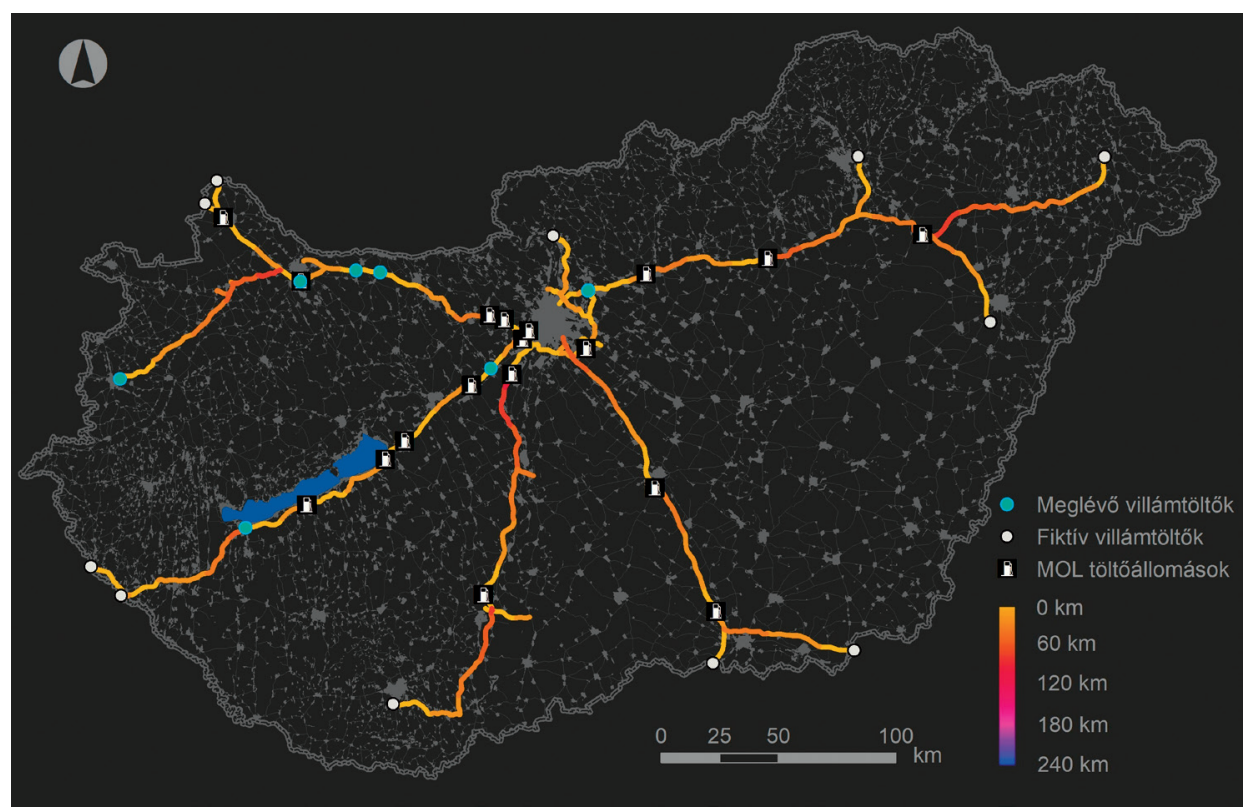

4. ábra Az E.ON-MOL-együttmúködés alapján végzett elérhetőségi vizsgálat eredményei Figure 4 Results of accessibility analysis based on the E.ON-MOL cooperation

A MOL-pihenőhelyek azonban egyenlőtlen eloszlásban helyezkednek el az ország autópályáin: míg az M7-esen 10, addig az M6-os és M5-ös autópálya vonalán 4-4 pihenóhely áll rendelkezésre. Például az M6-os Budapest felé tartó vonalán, a Pécs közelébe helyezett fiktív töltőponttól indulva 90 km távolságra fekszik az első (Fácánkerti) MOL-töltóállomás, 
majd a következő, százhalombattai „Keresztúri pihenő” további 105 km-re. Ezzel szemben, az M7-es fóváros felől kivezető vonalán, a budaörsi MOL-benzinkút és a balatonkeresztúri villámtöltő közötti 160 km-es szakaszon 4 MOL-benzinkút és 1 már jelenleg is üzemelő elektromos töltőállomás található. Azonban Balatonkeresztúrtól a tornyiszentmiklósi határátkelőhelyig tartó $90 \mathrm{~km}$-es szakaszon - potenciális töltőállomás-befogadóként - nem áll rendelkezésre egyetlen egy MOL-töltőállomás sem.

Bár a MOL-töltőállomásokon telepítendő villámtöltők önmagukban is képesek lennének biztosítani a magyarországi tranzitútvonalak átjárhatóságát, a jövőben számos más szolgáltató hozzájárulása valószínúsíthető a töltőállomások széles körű elérhetőségéhez.

\section{A BME KKT-kutatás eredményeinek elemzése}

E részkutatás keretében a CsISzÁR Cs. et al. (2018) által javasolt 70 villámtöltő közül leválogattuk az autópályák mentén lévő 60 helyszínt, amelyek közül 4-ben már jelenleg is üzemel villámtöltő. A BME KKT által javasolt potenciális töltőállomás-helyszíneket kifejezetten a közúthálózat mentén lévő üzemanyagtöltő-állomásokra helyezték el. Ennek az az oka, hogy a kiegészítő szolgáltatások meglétét, emellett a villamosenergia-hálózat kiépítettségét is figyelembe vették, ezáltal a lehetséges helyszínek száma leszúkült a már meglévő pihenőhelyekre, különösen a benzinkutakra. Ezek alapján a magyarországi autópályák vonalán elérhető 82 üzemanyagtöltő-állomásból 58 helyszínre került potenciális töltőpont. Emellett a már szintén meglévő, de az általuk javasolt helyszínekkel nem egyező töltőket is felhasználtuk, ugyancsak a korábban alkalmazott fiktív töltőpontokkal együtt. A modell futtatása során így összesen 72 helyszínt vettünk figyelembe (5.ábra).

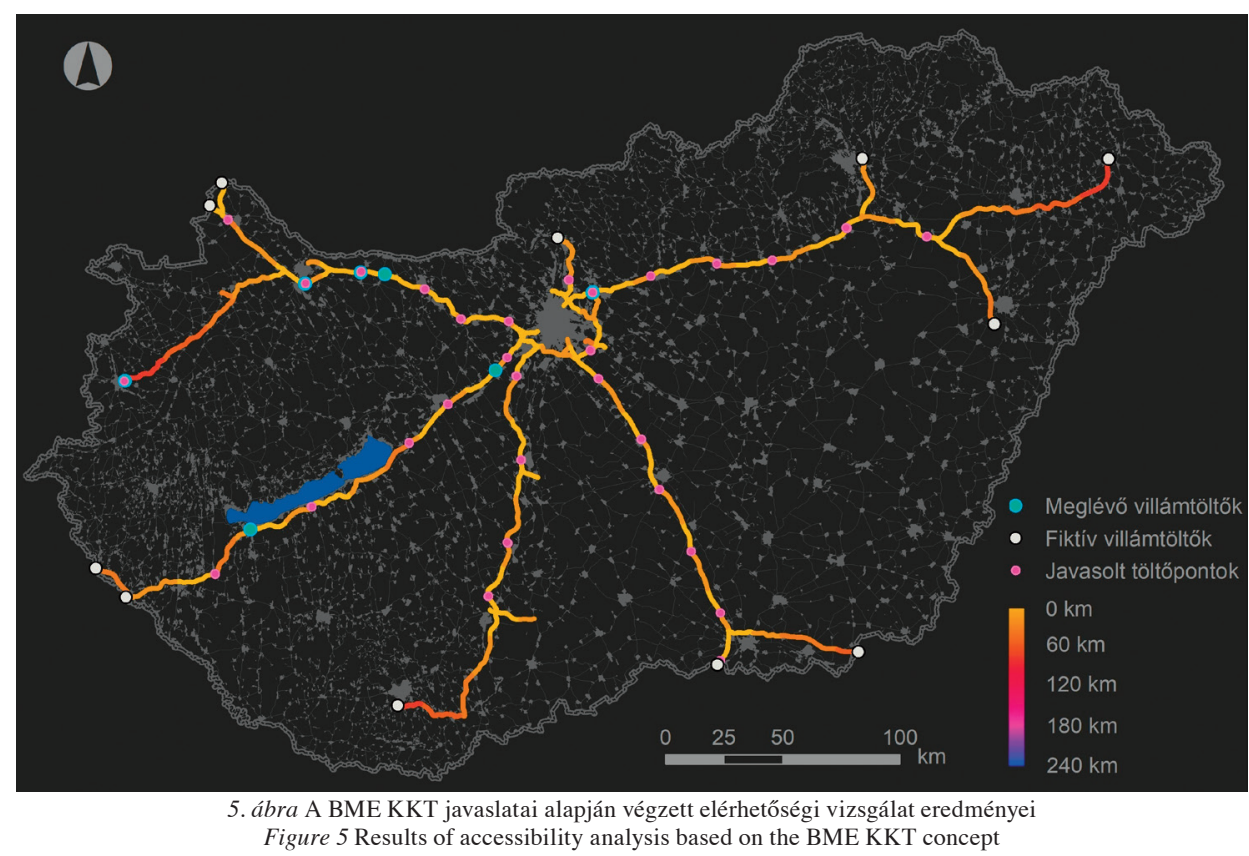

Bár a BME KKT vizsgálata kifejezetten Magyarország teljes lefedettségére irányult, a tanulmányukban javasolt töltőállomás-helyszínek modellezésünk alapján megfeleló sürüségben vannak ahhoz is, hogy biztosítsák az ország gyorsforgalmi átjárhatóságát. 
A javasolt töltőpontoktól számított 20 km-es távolságon belülre eső útszakaszok 48,9\%-ot tesznek ki a modellezés során figyelembe vett gyorsforgalmi utak teljes hosszához képest, míg a 20-40 km közötti szakaszok 32,7\%-ot, a 40-60 km közötti szakaszok pedig 10,5\%-ot.

\section{Az ELTE KTF eredményei}

A saját javaslatok alapján kijelölt töltőpontok száma 99 helyszínt foglal magába, amelyek közül 8 teljesen megegyezik a jelenleg már üzemben lévő töltőkkel, ugyanakkor kiegészül a fiktív töltőpontokkal, ami összesen 106 helyszínt eredményez. Az első körben javasolt töltőállomásokkal lefuttatott elérhetőségi vizsgálat esetében a potenciális töltőpont-helyszínektől számított $20 \mathrm{~km}$-en belülre eső szakaszok a teljes vizsgált úthossznak 59,1\%-át adják, míg a 20 és $40 \mathrm{~km}$ között ez az érték 29,9\%, a 40 és $60 \mathrm{~km}$ közötti pedig 7,4\%. Ezáltal a gyorsforgalmi utak teljes hosszának 96,5\%-a az első három kilométer-kategóriába tartozik. Azonban még ennek ellenére is megjelennek olyan töltóhiányos szakaszok, ahol a két töltési lehetőség között lévő útszakasz hossza meghaladja az 50 km-t (6. ábra). Ez a távolság egy alacsony akkumulátor-töltöttségű személyautó esetében már kockázatos lehet, ezért az ilyen szakaszokon is szükséges a megfelelö számú villámtöltók kialakítása.

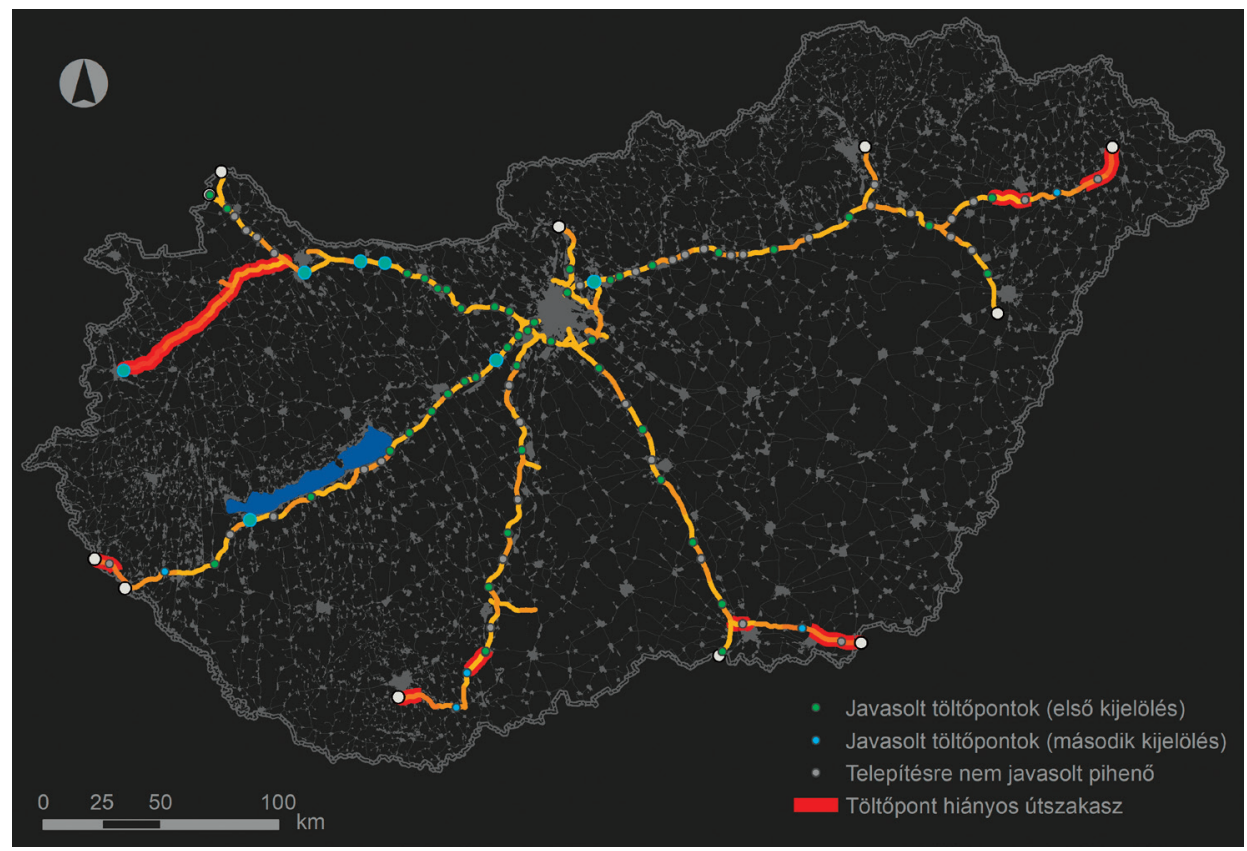

6. ábra Az ELTE KTF-módszertan alapján végzett 1. körös elérhetőségi vizsgálat eredményei Figure 6 Results of accessibility analysis based on the 1st phase of the ELTE KTF methodology

A második körös kijelölés esetében, a szükséges szakaszokon, további 7 helyszín hozzáadását követően, 113 pont vett részt a vizsgálatban. A módszer az alkalmazott hiátusokat kitöltő eljárás alapján megfelelőnek bizonyult. Az újbóli modellfuttatás eredményeinek alapján javasolt töltôpontoktól számított $20 \mathrm{~km}$-en belülre eső kumulált távolság a teljes úthossz 63,4\%-a, míg a 20 és 40 km közötti kategóriában 31,3\%, a 40 és 60 km közötti pedig 2,7\%. Ezáltal az első, második és harmadik távolság-kategóriába eső területek a teljes gyorsforgalmi úthossz 97,4\%-át jelentik, ami az első körös kijelöléshez képest 0,9\%-os javulást jelent. 
A leghosszabb útszakasz, ahol nem áll rendelkezésre pihenőhely, az M86-os autóuton található. Ezen az új építésú szakaszon ennek következtében nincs lehetôség töltőhelyszín kijelölésére sem az első, sem a második kijelölés során. Ebben az esetben a két meglévő töltőállomás (a győrújbaráti és a szombathelyi villámtöltő) között jelentős, 100 km a távolság, ami egy átlagos elektromos személyautó számára optimális üzemi körülmények között teljesíthető, azonban kedvezőtlen körülmények között fennállhat az akkumulátor lemerülésének veszélye (7. ábra). Tehát amíg az M86-os autóton nem létesül pihenôhely és nem alakítható ki elektromos töltóállomás, addig a legvalószínúbb megoldás az útvonalról való letérés és a közelben történő feltöltés (ám jelenleg csak 1 villámtöltő érhető el az út 5 km-es körzetében, Csornán).

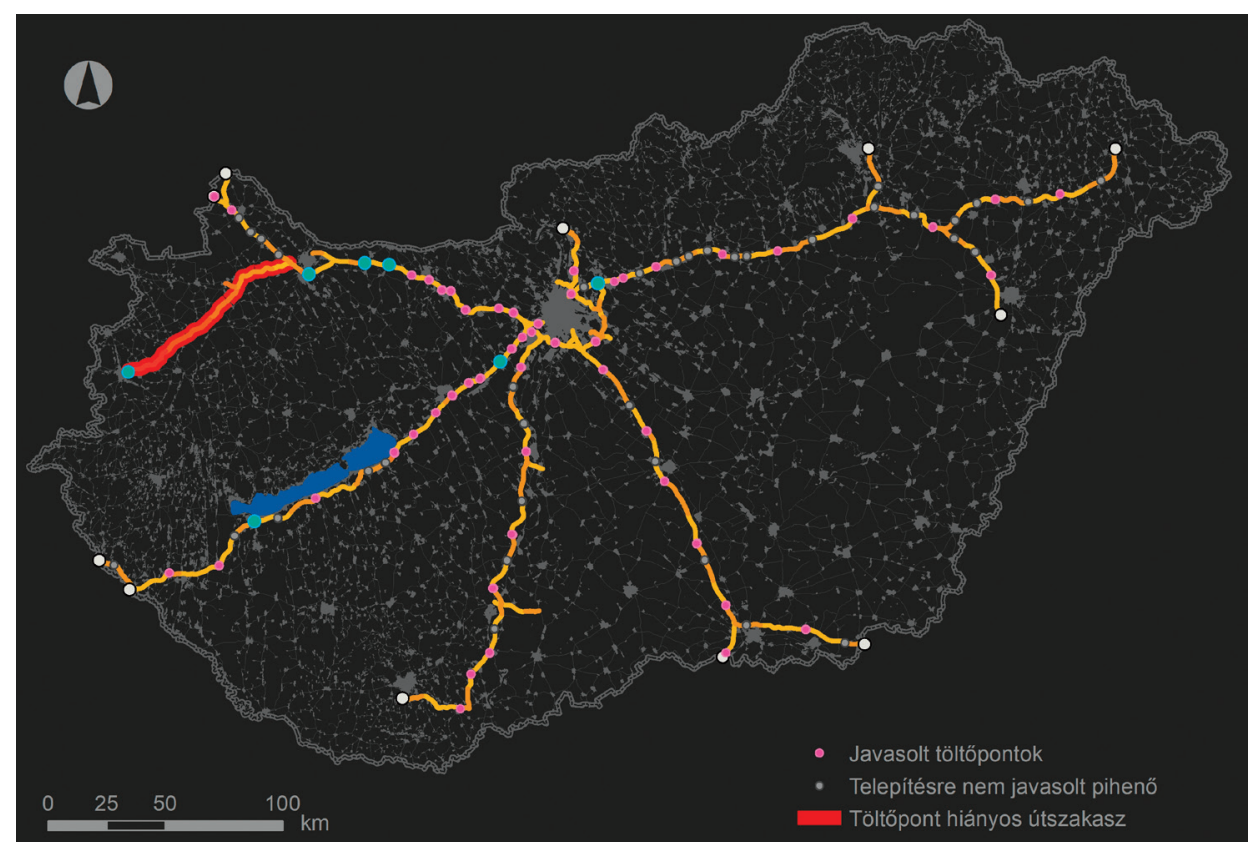

7. ábra Az ELTE KTF-módszertan alapján végzett 2. körös (végleges) elérhetőségi vizsgálat eredményei Figure 7 Results of accessibility analysis based on the 2nd (final) phase of the ELTE KTF methodology

Az eredmények alapján a villámtöltőknek az ELTE KTF módszertana által javasolt telepítése lehetôvé tenné az ország átjárhatóságát a gyorsforgalmi utak mentén, akár a legalacsonyabb hatótávval rendelkező elektromos hajtású jármúvel is (kivéve az imént bemutatott pihenőhely- és töltőállomás-hiányos területen). Ami elhelyezkedésüket illeti, Budapest irányába haladva a forgalom volumenének növekedésével a javasolt töltőállomások egyre sűrúbben fordulnak elő, ami jól látható az M1-es és M7-es autópálya mentén. Ezeken a területeken több lehetôség állhat rendelkezésre az autó feltöltésére, ezáltal a sűrû töltőállomásokkal rendelkező útszakaszokon eloszlanak a töltendő jármúvek.

\section{A fejlesztési elképzelések összehasonlitása}

Az E.ON-MOL, a BME KKT és az ELTE KTF módszertana alapján meghatározott töltőállomások figyelembevételével készített vizsgálatok egymással összehasonlíthatók, hiszen - bár különböző megközelítéssel, de - mindhárom esetben az ország átjárhatóságát 
biztosító elektromos töltőhálózat potenciális helyszíneinek kijelölése volt a cél. A három elemzés között a töltőpontoktól számított 20 kilométerenként meghatározott kategóriák alapján figyelhetők meg a legnagyobb különbségek, amelynek százalékos megoszlását a 8. ábra oszlopdiagramjai szemléltetik. Az egyes távolsági kategóriákra jutó részarányok forgatókönyvek közötti változásai jól illusztrálják, hogy a nagyobb elemszámú, racionális helyszínkiválasztás kedvezően hat a töltőpontok szolgáltatási „,területeire”. Az E.ON-MOL által meghatározott helyszínek esetében a potenciális töltők között 100 és 120 km távolság is előfordulhat, bár ezek a gyorsforgalmi utak teljes úthosszának csupán 1\%-át adják, ami mindössze 27,5 km. Ezzel szemben a BME KKT- és az ELTE KTF-kutatás által javasolt töltőpontok esetében nincs 100 km-nél hosszabb lefedetlen útszakasz. Emellett, míg a 40 és 100 km közé eső úthossz a BME KKT elemzésében összesen 521,4km, addig a saját (ELTE KTF) módszertan szerint mindössze 153,2 km. Ezek az értékek lényegesen magasabbak az E.ON-MOL elképzeléseiben, hiszen a 40 és 100 km közötti távolságban lévő szakaszok hossza 937,1 km (33,2\%).

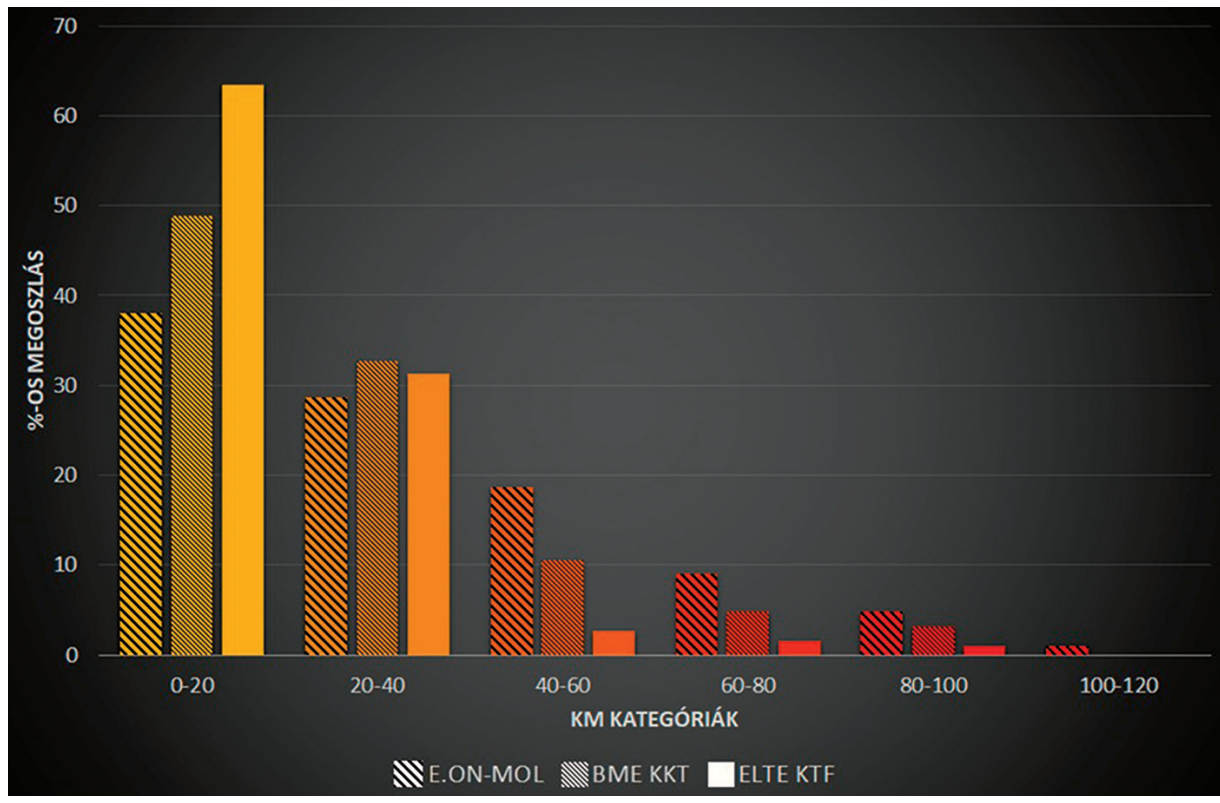

8. ábra Az egyes útszakaszok távolság kategóriákba való besorolásának százalékos megoszlása az E.ON-MOL, a BME KKT- és az ELTE KTF-módszertan alapján

Figure 8 Percentage breakdown of distance categories of road segments based on E.ON-MOL, BME KKT and ELTE KTF concepts

A töltőpontoktól számított 20 km-en belüli kategória esetén is látható a különbség, hiszen összehasonlítva az ELTE KTF eredményeivel, a BME KKT-tanulmány össz-távolsága között 430 km a különbség, míg az E.ON-MOL esetében ez az érték 686 km. Ennek a legfőbb oka nyilvánvalóan az, hogy mind a BME KKT tanulmányában, mind pedig az E.ON-MOL célkitűzésében javasolt töltőállomás-helyszínek számánál több helyszínt javasoltunk a három forgatókönyv felvetéseit összehasonlító modellezés során (1. táblázat). A lehető legkedvezőbb helyzetet, vagyis hazánk autópályáinak optimális átjárhatóságát természetesen azzal lehetne elérni, ha minden alkalmas pihenőben elektromosautó-töltőpontokat alakítanának ki. 
Az E.ON-MOL-, a BME KKT- és az ELTE KTF-módszertan eredményeinek összehasonlítása

Results comparison of E.ON-MOL, BME KKT and ELTE KTF concepts

\begin{tabular}{lccccccc}
\hline \multirow{2}{*}{ Módszertan } & $\begin{array}{c}\text { Töltőpontok } \\
\text { Száma }\end{array}$ & \multicolumn{6}{c}{ Kúvolságkategóriák szerinti bontásban, km } \\
& 53 & 1124 & 846 & 550 & 264 & 141 & 28 \\
\hline E.ON-MOL & 72 & 1380 & 923 & 298 & 134 & 90 & 0 \\
BME KKT & 106 & 1810 & 894 & 79 & 44 & 30 & 0 \\
ELTE KTF & $10-20$ & $\mathbf{2 0 - 4 0}$ & $\mathbf{4 0 - 6 0}$ & $\mathbf{6 0 - 8 0}$ & $\mathbf{8 0 - 1 0 0}$ & $\mathbf{1 0 0 - 1 2 0}$ \\
\hline
\end{tabular}

\section{Összefoglalás}

Fontos egyértelmúvé tenni, hogy a vizsgált koncepciók más-más szempontok alapján igyekeztek meghatározni a töltőállomások helyszíneit. Míg az E.ON-MOL javaslatai az üzleti érdekek mentén jelölték ki a potenciális helyszíneket, addig a BME KKT koncepciójának célja a minél átfogóbb területi lefedettség volt. Az ELTE KTF kidolgozta módszertan ezekkel szemben átjárhatósági optimalizációra törekedett a helyszínek kiválasztása során. Következésképp a három koncepció egymással csak bizonyos mértékig vethető össze, de jelen kutatásnak nem is volt célja bármiféle rangsorolás ezek között.

A modellezés során kirajzolódott, hogy a gyorsforgalmi utak mentén jelenleg rendelkezésre álló elektromosautó-töltőhálózat a hosszú távú elektromos autózás követelményeinek kielégítésére csak korlátozottan alkalmas. A vizsgálat arra enged következtetni, hogy a már meglévő a töltőállomások térbeli elhelyezésekor nem az országos átjárhatóság megteremtése volt a stratégiai cél, hiszen jelenleg a töltóállomások mindössze 5\%-a helyezkedik el az autópályák közvetlen közelében és ennek csupán a fele villámtöltő, amelyek hosszú távú közlekedés kielégítéséért volnának felelősek.

Jelen kutatás arra igyekezett rávilágítani, hogy célszerú volna olyan állami programot kezdeményezni, amelyben a térinformatika eszközrendszerét felhasználva a töltôhálózat helyszíneit optimálisan lehetne megtervezni és kivitelezni. Előbb-utóbb bizonyosan minden alkalmas helyszínt, így a pihenőhelyeket és üzemanyagtöltő-állomásokat is fel kell majd használni elektromos autók töltését szolgáló állomások kialakítására, de addig is fontos volna a telepítés térbeliségének és ütemezésének optimalizálása, vagyis annak figyelembevétele, hogy hol vannak jelenleg ebből a szempontból a legkritikusabb útszakaszok (pl. M86 autópálya). Ezeket a tapasztalatokat a jövőbeli gyorsforgalmi utak fejlesztési projektjeiben már a tervezéskor indokolt volna figyelembe venni.

Ugyanakkor fontos hangsúlyozni, hogy az elektromos autók és a töltőhálózat gyors fejlődése is gyorsan amortizálja a téma kutatása során felszínre kerülő összefüggéseket és eredményeket. Az akkumulátor-kapacitások növekedése elméletileg a töltőpont-hálózat térbeli ritkulásához is vezethetne, ám az elektromos jármúvek számának gyors növekedése ezzel ellentétes folyamatot generál, miközben a szinte naponta telepített új töltőpontok gyorsan rajzolják át a korábban felvázolt képet (DiXON, J.-BELL, K. 2020). A változás ütemét jól érzékelteti, hogy jelen kutatómunka megkezdése és lezárása közötti időszakban (2019. szeptember 12-2020. július 26.) 192 új nyilvános elektromos töltőt, köztük 38 villámtöltôt létesítettek hazánkban, ami rendre 28,7\%-os, illetve 28,3\%-os bővülést jelent. 
Ugyanakkor villámtöltőkből ez idő alatt mindössze hármat helyeztek el közvetlenül valamelyik autópályánkon.

\author{
SOHA TAMÁS \\ ELTE TTK Környezet- és Tájföldrajzi Tanszék, Budapest \\ tamas.soha@gmail.com
}

NÉMETH IZABELLA

KTI Közlekedésfejlesztési Kutatóközpont Hálózattervezési Osztály, Budapest nemeth.izabella@kti.hu

\author{
MunKÁCsy BÉLA \\ ELTE TTK Környezet- és Tájföldrajzi Tanszék, Budapest \\ munkacsy.bela@ttk.elte.hu
}

\title{
IRODALOM
}

Alegre, S.-Míguez, J. V.-CARPIO, J. 2017: Modelling of electric and parallel-hybrid electric vehicle using Matlab/Simulink environment and planning of charging stations through a geographic information system and genetic algorithms. - Renewable and Sustainable Energy Reviews 74. pp. 1020 -1027.

CAPAR, I.-Kuby, M. 2012: An efficient formulation of the flow refueling location model for alternative-fuel stations. - IIE Transactions 44. 8. pp. 622-636.

Chung, S. H.-Kwon, C. 2015: Multi-period planning for electric car charging station locations: A case of Korean Expressways. - European Journal of Operational Research 242. 2. 16. pp. 677-687.

Csiszár Cs.-Csonka B.-Földes D.-WirTh E.-Lovas T. 2018: Az országos átjárhatóságot biztosító elektromos villámtöltő-állomások helyszínét kijelölő módszer. - Közlekedéstudományi Szemle 68. 1. pp. 14-25. doi:10.24228/KTSZ.2018.1.2

DiXON, J.-BELL, K. 2020: Electric vehicles: battery capacity, charger power, access to charging and the impacts on distribution networks. - eTransportation 5. pp. 1-18. doi:10.1016/j.etran.2020.100059

DMCEU 2019: Denmark's Integrated National Energy and Climate Plan. - Danish Ministry of Climate, Energy and Utilities, Copenhagen. 184 p.

https://ens.dk/en/our-responsibilities/energy-climate-politics/eu-energy-union-denmarks-national-energyand-climate

Dong, G.-MA, J.-WEI, R.-HAYCOX, J. 2019: Electric vehicle charging point placement optimisation by exploiting spatial statistics and maximal coverage location models. - Transportation Research Part D 67. pp. 77-78.

Európa Tanács 2019: Az európai zöld megállapodás (EU Green Deal). https://eur-lex.europa.eu/legal-content/EN/TXT/?qid=1588580774040\&uri=CELEX:52019DC0640

Frade, I.-Ribeiro, A.-Gonçalves, G.-Antunes, A. P. 2011: Optimal Location of Charging Stations for Electric Vehicles in a Neighborhood in Lisbon, Portugal. - Transportation Research Record: Journal of the Transportation Research Board 2252. 1. pp. 91-98. doi:10.3141/2252-12

GERSE J. 2020: Felvillanyozva: az elektromos autók töltőhálózatának terjedése Magyarországon. - Területi Statisztika 60. 4. pp. 461-476. DOI: 10.15196/TS600403

Hanabusa, H.-HoRiguhCi, R. 2011: A Study of the Analytical Method for the Location Planning of Charging Stations for Electric Vehicles. - Lecture Notes in Computer Science pp. 596-605. doi:10.1007/978-3-64223854-3_63

He, Y.-Kockelman, K. M.-Perrine, K. A. 2019: Optimal locations of U.S. fast charging stations for long-distance trip completion by battery electric vehicles. - Journal of Cleaner Production 214. pp. 452-461. doi:10.1016/j.jclepro.2018.12.188

Hodgson, M. J. 1990: A Flow-Capturing Location-Allocation Model. Geographical Analysis 22.3. pp. $270-279$.

Kuby, M.-Lim, S. 2004: The flow-refueling location problem for alternative-fuel vehicles. - Socio-Economic Planning Sciences 39. pp. 125-145.

LIU, J. 2012: Electric vehicle charging infrastructure assignment and power grid impacts assessment in Beijing. - Energy Policy 51. pp. 544-557. doi:10.1016/j.enpol.2012.08.074

Pevec, D.-Babic, J.-Carvalho, A.-Ghiassi-Farrokhfal, Y.-Ketter, W.-Podobnik, V. 2020: A SurveyBased Assessment of How Existing and Potential Electric Vehicle Owners Perceive Range Anxiety. - Journal of Cleaner Production 276. 10. pp. 1-23. doi:10.1016/j.jclepro.2020.122779 
PWC Magyarország 2013: Kitekintés az elektromos autók jövőjére. - 13 p. https://www.pwc.com/hu/hu/kiadvanyok/assets/pdf/e-car-survey-hu.pdf

ShAHRAKI, N.-CAI, H.-TURKAY, M.-XU, M. 2015: Optimal locations of electric public charging stations using real world vehicle travel patterns. - Transportation Research Part D: Transport and Environment 41. pp. 165-176.

\section{Felhasznált adatbázisok:}

E.ON - Villámtöltő telepítések adatbázisa https://www.eon.hu/hu/kozigazgatasi/termekek/villamtolto-telepites.html

MK Nonprofit Zrt. 2018: Az országos közutak 2018. évre vonatkozó keresztmetszeti forgalma https://internet.kozut.hu/kozerdeku-adatok/orszagos-kozuti-adatbank/forgalomszamlalas

MOBILITI (NKM TÖLTŐPONT) mobiltelefonos applikáció adatbázisa. https://toltopont.eu/ 